\section{Glucoraphanin Level in Broccoli Seed is Largely Determined by Genotype}

\author{
Mark W. Farnham \\ U.S. Department of Agriculture, Agricultural Research Service. U.S. Vegetable \\ Laboratory, 2700 Savannah Highway, Charleston, SC 29414
}

\section{Katherine K. Stephenson}

Lewis B. and Dorothy Cullman Cancer Chemoprotection Center, Department of Pharmacology and Molecular Sciences, School of Medicine, Johns Hopkins University, Baltimore, MD 21205

\section{Jed W. Fahey \\ Lewis B. and Dorothy Cullman Cancer Chemoprotection Center, Department of Pharmacology and Molecular Sciences, School of Medicine, and Center for Human Nutrition, Bloomberg School of Public Health, Johns Hopkins University, Baltimore, MD 21205 \\ Additional index words. Brassica oleracea, doubled-haploids, broccoli sprouts, glucosinolates, glucoiberin, chemoprotection}

\begin{abstract}
Broccoli (Brassica oleracea L., Italica Group) seed and resulting sprouts can contain high levels of glucoraphanin, a glucosinolate, which can be converted to sulforaphane, a compound with cancer protective and antioxidant properties. This observation has stimulated interest in broccoli seed production. In this study, inbred lines, which produce relatively high yields of homogeneous, selfed-seed across different environments in the absence of insect pollinators, were used to evaluate the relative importance of genotype versus environment as a determinant of glucoraphanin concentration in broccoli seed. Glucoraphanin and glucoiberin were measured in broccoli seed lots generated from ten broccoli inbred lines grown in two greenhouse and two screen cage environments. Typically, seed glucoraphanin level ranged from 5 to $100 \mu \mathrm{mol} \cdot \mathrm{g}^{-1} \mathrm{seed}$ and glucoiberin ranged from 0 to about $40 \mu \mathrm{mol} \cdot \mathrm{g}^{-1}$ seed, regardless of the environment in which seed was produced. Analysis of variance indicated that genotype was the most significant factor influencing levels of the two glucosinolates. Although significant environmental and genotype $\times$ environment effects were observed for glucoraphanin and a significant genotype $x$ environment effect was observed for glucoiberin, these effects were small compared to the genotype effects. Results indicate that it is possible to identify broccoli inbreds that consistently produce relatively high yields of seed with a high glucoraphanin content across different environments.
\end{abstract}

Interest in broccoli (Brassica oleracea L., Italica Group) has risen significantly over the last decade as consumers increasingly recognize this vegetable as a functional food that confers a health benefit. In addition to high levels of fiber, vitamins, and minerals, broccoli contains a glucosinolate, glucoraphanin (4-methylsulfinylbutyl glucosinolate), which has been deemed an important phytochemical due to the multiplicity of health-promoting effects that its primary metabolite, sulforaphane, confers (Zhang et al., 1992).

Briefly, glucosinolates are B-thioglucoside $N$-hydroxysulfates with an aglycone (or R-group) that is an alkyl, alkenyl, thioalkyl, thioalkenyl, aryl, arylalkyl or indolyl moiety (reviewed by Fahey et al., 2001; Rosa et al., 1997). These compounds are hydrolyzed to isothiocyanates by the enzyme myrosinase when plant cells are damaged (e.g., chewed),

Received for publication 6 Feb. 2004. Accepted for publication 27 May 2004. Mention of trade names or commercial products in this publication is solely for the purpose of providing specific information and does not imply recommendation or endorsement by the U.S. Department of Agriculture. or in the human gut as a result of microbial activity (Shapiro et al., 1998). Glucoraphanin is thus converted to the isothiocyanate, sulforaphane, which has been the focus of much recent scientific attention. Sulforaphane (4methylsulfinylbutyl isocyanate) is a potent inducer of mammalian detoxication (phase 2) and antioxidant enzyme activity that protects against tumorigenesis in rodent mammary, stomach, and prostate tumor models (Fahey et al., 1997, 2002; Jackson and Singletary, 2004; Singh et al., 2004; Zhang et al., 1992, 1994). It has also been shown to reduce hypertensive stress and to cure Helicobacter pylori infection (Fahey et al., 2002; Haristory et al., 2003; Wu and Juurlink, 2001).

Fahey et al. (1997) showed that broccoli seeds and sprouts (i.e., 3-d-old seedlings) contain 10 to 100 times more glucoraphanin, on a weight basis, than mature broccoli heads. Subsequently, work with these sprouts and their active components (Brooks et al., 2001; Fahey and Talalay, 1999), has stimulated commercial interest in broccoli sprouts as new food products. Recent broccoli seed production increases, stimulated by the demand for sproutable seed, has made use of existing open-pollinated (OP) cultivars (e.g., 'Calabrese' and 'DeCicco'). Although seed can be produced cheaply with these OP cultivars, a problem with resulting seed lots is that they are genotypically, a very heterogeneous mixture. As a consequence, seed characteristics, including glucoraphanin level, are highly variable. Recently, Farnham and Harrison (2003) proposed an alternative source of inexpensive broccoli seed derived from selfcompatible inbreds. Such inbreds, derived from the above-mentioned OP cultivars and from a doubled haploid (DH) breeding program, yield broccoli seed in the absence of insect pollinators (Farnham and Harrison, 2003). Seed lots harvested from these inbreds are homogeneous. Theoretically, such homogeneous seed will produce more uniform sprouts with uniform glucoraphanin levels than OP cultivars. The recognition of self-compatible individuals in broccoli as well as independent selfed-seed production, were first reported by Moore and Anstey (1954) in what was previously considered an almost exclusively cross-pollinated crop. Subsequently, some investigators have proposed that self-compatible inbreds could be used directly as broccoli cultivars (Gray, 1993).

Glucoraphanin is the most abundant aliphatic glucosinolate present in harvested florets of most broccoli cultivars; however, other aliphatic glucosinolates, such as glucoiberin (3-methylsulfinyl propyl glucosinolate) are also present in broccoli tissues. In florets, glucoiberin typically occurs at levels less than $10 \%$ of glucoraphanin levels (Carlson et al., 1987; Kushad et al., 1999; Shelp et al., 1993), and in some cultivars glucoiberin cannot be detected. Its cognate isothiocyanate, iberin, typically accounts for $<2 \%$ of total glucosinolate-derived phase 2 enzyme induction potency of broccoli (Prestera et al., 1993; Zhang et al., 1992). Glucoiberin also occurs at higher levels in broccoli seed than in florets (Fahey et al., 1997; Pereira et al., 2002).

Broccoli genotype has a significant effect on glucoraphanin levels in plant tissues (Faulkner et al., 1998; Giamoustaris and Mithen, 1996; Kushad et al., 1999; Li et al., 2001; Pereira et al., 2002). Several studies (Brown et al., 2002; Farnham et al., 2000, 2004; Rosa et al., 2001) have examined and identified interactions between genotype and environment on levels of glucoraphanin in broccoli tissues. Brown et al. (2002) estimated a moderately high broad sense heritability of $54 \%$ for this trait. Farnham et al. (2000) and Rosa et al. (2001) found high correlations between glucoraphanin expression in one environment and a second. Farnham et al. (2004) also showed that genotypic effects on glucoraphanin concentration and phase 2 enzyme induction potential are much larger than environmental or genotype by environment effects.

We are unaware of any studies that have examined the relative effects of genotype and environment on expression of glucoraphanin or glucoiberin content of broccoli seed. This study was therefore undertaken to determine glucoraphanin and glucoiberin levels in seed harvested from self-compatible broccoli inbreds grown in two greenhouse and two screen cage trials and to evaluate the relative 
influences of genotype versus environment in determination of the levels of these compounds in broccoli seed.

\section{Materials and Methods}

Plantmaterial.Eleven broccoli entries were previously grown and described in two greenhouse and two screen cage tests wherein seed production was evaluated (Farnham and Harrison, 2003). Three inbred entries were derived from the OP cultivars DeCicco, Atlantic, and Italian Green Sprouting; these inbreds were designated USVL102, USVL103, and USVL104, respectively. Seven other inbreds, including USVL020, USVL028, USVL036, USVL043, USVL049, USVL062, and USVL093, are DH lines developed by one of us (Farnham, 1998). All of these entries were shown to be self-compatible lines that produce viable seed in the absence of insect pollinators. Certain of these lines produced relatively large and consistent amounts of seed compared to others (Farnham and Harrison, 2003). An additional entry grown in the previous study was the $F_{1}$ hybrid cultivar Pinnacle. It was a poor seed producer, but upon selfing, it yielded small numbers of viable seed.

Greenhouse and screen cage trials. Two greenhouse trials conducted in 1998-99 and 1999-2000 and two outdoor screen cage trials conducted in 1999-2000 and 2000-01 at Charleston, S.C., were described in detail previously (Farnham and Harrison, 2003). All trials were arranged in randomized complete block designs. In the greenhouse, plants were arranged in five blocks (replications), each containing 12 plants (one for each entry), randomly arranged within a block and spaced so as not to be in contact with one another. Screen cage experiments were arranged such that each of three cages was considered a block. Growth of plants, harvesting, and handling of seed were all described previously (Farnham and Harrison, 2003). When plants reached a stage at which $50 \%$ of the siliques were yellow to brown, all siliques were harvested by cutting the mature racemes from the plants and placing them in paper bags. Bags with harvested siliques were left in the greenhouse and dried for about 2 weeks. All seed was then manually threshed out of siliques and nonseed trash was removed. Seeds were placed in envelopes and allowed to dry further at $25^{\circ} \mathrm{C}$ and $<50 \%$ relative humidity. After two weeks, seed was moved to a seed storage facility at $10{ }^{\circ} \mathrm{C}$ and $50 \% \mathrm{RH}$ for 4 weeks and then weighed.

Preparation and glucosinolate analysis of seed extracts. Broccoli seed extracts were prepared essentially as described in Fahey et al. (1997). Briefly, about $100 \mathrm{mg}$ of seed (about 20 to 25 seeds) from each seed lot was homogenized in a 10-fold excess (vol/wt) of triple solvent (equal volumes of DMSO, dimethylformamide, and acetonitrile), and an aliquot was removed for HPLC analysis. Analytical detection of glucosinolates was performed on a Waters HPLC (Waters Corp., Milford, Mass.) using a $3 \mu \mathrm{m}, 4.6 \times 100$ $\mathrm{mm}$ polyhydroxyethylaspartamide column (PolyLC Corp., Columbia, Md.) run under isocratic conditions at $2 \mathrm{~mL} \cdot \mathrm{min}^{-1}$ using ammonium formate at a final concentration of 30 $\mathrm{mm}$ and at $\mathrm{pH} 5.4$, in $85 \%$ acetonitrile : $15 \%$ water (Troyeret al., 2001), with the photo diode array detector set at $235 \mathrm{~nm}$. Retention times for elution of glucoraphanin and glucoiberin under these conditions was about 12 and 13 min, respectively, with a response factor of $170,000 \mu \mathrm{V} \cdot \mathrm{s}^{-1} \cdot \mathrm{nmol}^{-1}$, based on a crystalline sinigrin standard (Sigma-Aldrich Chemical Co.). Confirmation of identity was made by comparison with standards whose identity was verified by HPLC, spectrophotometry and mass spectrometry (Troyer et al., 2001; Prestera et al., 1996). The $\mathrm{m} / \mathrm{z}$ for the molecular ions of glucoraphanin and glucoiberin were 436 and 422 amu respectively, by electrospray mass spectrometry on a mass spectrometer (model API 150EX; Applied Biosystems, Foster City, Calif.), in accordance with expectations.

Statistical analysis. Analysis of Variance was conducted using Proc GLM of SAS (release 6.12, SAS Institute, Inc., Cary, N.C.). Data for total seed weight per plant were analyzed as described previously (Farnham and Harrison, 2003). Total yield of glucoraphanin and glucoiberin per plant was calculated for each experimental unit by multiplying glucosinolate concentration by seed weight. Glucosinolate concentrations and yields per plant were assessed in a combined analysis of all trials to test for significant environment, genotype, and genotype by environment effects. In addition, these characteristics were evaluated for each individual environment specifically, to assess genotype effects. Glucoraphanin and glucoiberin concentrations of all entries in a given environment were also ranked, and a Spearman rank correlation was conducted under Proc Corr of SAS to compare ranks between environments.

\section{Results and Discussion}

Farnham and Harrison (2003) previously demonstrated that OP cultivar-derived selections and DH lines can be good sources of selfed broccoli seed. They identified two OP cultivar-derived lines (USVL102 and 104) and two DH lines (USVL062 and USVL093) that produced relatively high and consistent seed yields in two greenhouse and two screen cage environments. The objective of the study reported upon herein was to evaluate the relative importance of genotype and environment as determinants of glucoraphanin and glucoiberin concentration in broccoli seed and to evaluate total glucoraphanin and glucoiberin yields based on analysis of harvested seed.

Analysis of variance based on the combined analysis of data from all four environments indicates that broccoli genotypes varied significantly both in concentration and in per-plant yields of both glucoraphanin and glucoiberin (Table 1).

There were significant environmental and genotype $\times$ environment effects on glucoraphanin levels, but these were much smaller in magnitude than the effect of genotype alone (Table 1). These results are similar to those observed with mature broccoli florets (Brown et al., 2002; Farnham et al., 2003; Rosa et al., 2001) in which there was a pronounced genotype effect on level of glucoraphanin in the florets. A few other researchers (Carlson et al., 1987; Rangkadilok et al., 2002; Velasco and Becker, 2000) have evaluated genotype effects on seed glucoraphanin in B. oleracea, and concluded that different broccoli genotypes vary significantly in glucoraphanin concentration. Carlson et al. (1987) reported relatively small differences among broccoli seed lots from different environments, but Rangkadilok et al. (2002) reported a range of 44.2 to 274.1 $\mu \mathrm{mol} \cdot \mathrm{g}^{-1}$. It is not possible to definitively differentiate among broccoli genotypes in any of these studies post-facto since the seed lots evaluated came from seed banks, and likely utilized varying production environments.

There were significant differences in seed glucoraphanin concentration among broccoli inbreds in every environment tested (Table 2). Seed glucoraphanin concentration ranged from $<10$ to $107.5 \mu \mathrm{mol} \cdot \mathrm{g}^{-1}$. There was an effect of environment with certain inbreds (i.e., USVL062 and USVL036), but it did not substantially affect their relative rankings (Table 2). For example, USVL049 had the second or third highest glucoraphanin in all environments, USVL028 was always seventh or eighth, USVL093 was always eighth or ninth, and USVL043 was always tenth or eleventh. Seed from the hybrid 'Pinnacle', which typically had the lowest seed yield, always had the highest glucoraphanin concentration. Spearman rank correlations of glucoraphanin concentrations between environments resulted in an average coefficient between environments of 0.92 that was highly siginificant, underscoring the consistency of these concentrations among the different environments. This is the first report that we are aware of showing that a) broccoli seed produced by different genotypes in a single environment have significantly different

Table 1. Mean squares from the analysis of variance (ANOVA) of glucoraphanin (GR) and glucoiberin (GI) seed concentrations $\left(\mu \mathrm{mol} \cdot \mathrm{g}^{-1}\right)$ and total yields ( $\left.\mu \mathrm{mol} / \mathrm{plant}\right)$ from seed evaluated in eleven broccoli genotypes grown in four environments.

\begin{tabular}{|c|c|c|c|c|c|}
\hline \multirow[b]{2}{*}{ Source } & \multirow[b]{2}{*}{$\mathrm{df}$} & \multicolumn{4}{|c|}{ Mean squares } \\
\hline & & $\begin{array}{c}\text { GR } \\
\text { concn }\end{array}$ & $\begin{array}{c}\text { GR } \\
\text { yield }\end{array}$ & $\begin{array}{c}\text { GI } \\
\text { concn }\end{array}$ & $\begin{array}{c}\text { GI } \\
\text { yield }\end{array}$ \\
\hline Environment & 3 & $1,387.7^{* *}$ & $18,132.5^{*}$ & 22.83 & 373.7 \\
\hline Replication (environment) & 12 & 174.3 & $3,696.0$ & 22.36 & 245.8 \\
\hline Genotype & 10 & $11,990.1^{* *}$ & $131,070.5^{* *}$ & $1,498.65^{* *}$ & $3,835.9^{* *}$ \\
\hline Genotype $\times$ environment & 30 & $311.4^{* *}$ & $14,399.1^{* *}$ & $37.02^{* *}$ & 253.5 \\
\hline Error & 120 & 104.1 & $7,589.5$ & 18.79 & 198.4 \\
\hline Total & 175 & & & & \\
\hline
\end{tabular}

*** Significant at $P \leq 0.05$ or 0.01 , respectively. 
Table 2. Mean glucoraphanin (GR) concentration ( $\mu \mathrm{mol} \cdot \mathrm{g}^{-1}$ seed) and total GR yield ( $\mu \mathrm{mol} / \mathrm{plant}$ ) for seed harvested from self-compatible inbreds grown in two greenhouse and two outdoor cage environments.Sources of inbreds include open-pollinated (OP) varieties or doubled haploid (DH) populations. The hybrid (F1) 'Pinnacle' was included as a check.

\begin{tabular}{|c|c|c|c|c|c|c|c|c|c|}
\hline \multirow{4}{*}{$\begin{array}{l}\text { Broccoli } \\
\text { inbred }\end{array}$} & \multirow[b]{4}{*}{ Source } & \multicolumn{4}{|c|}{ Concn $\left(\mu \mathrm{mol} \cdot \mathrm{g}^{-1}\right.$ seed $)$} & \multicolumn{4}{|c|}{ Yield ( $\mu$ mol/plant) } \\
\hline & & $\mathrm{GH}$ & $\mathrm{GH}$ & Cage & Cage & $\mathrm{GH}$ & $\mathrm{GH}$ & Cage & Cage \\
\hline & & 1999- & $2000-$ & $2000-$ & 2001- & 1999- & 2000- & $2000-$ & 2001- \\
\hline & & 2000 & 2001 & 2001 & 2002 & 2000 & 2001 & 2001 & 2002 \\
\hline$\overline{\text { USVL102 }}$ & OP & 53.5 & 91.0 & 40.4 & 45.4 & 78.7 & 195.2 & 203.6 & 393.0 \\
\hline USVL104 & $\mathrm{OP}$ & 52.3 & 72.5 & 57.6 & 64.6 & 188.7 & 439.0 & 300.7 & 232.8 \\
\hline USVL103 & $\mathrm{OP}$ & 48.2 & 32.9 & 42.5 & 29.4 & 44.6 & 12.7 & 92.8 & 56.7 \\
\hline USVL049 & DH & 72.6 & 80.5 & 60.9 & 60.3 & 197.7 & 293.3 & 84.5 & 161.3 \\
\hline USVL062 & $\mathrm{DH}$ & 7.8 & 13.5 & 3.3 & 3.3 & 28.3 & 25.4 & 10.7 & 10.3 \\
\hline USVL093 & $\mathrm{DH}$ & 19.3 & 21.7 & 15.9 & 17.1 & 69.4 & 77.8 & 22.1 & 50.3 \\
\hline USVL020 & $\mathrm{DH}$ & 20.2 & 39.2 & 14.5 & 20.8 & 45.5 & 71.7 & 31.3 & 47.1 \\
\hline USVL028 & $\mathrm{DH}$ & 24.2 & 32.8 & 26.0 & 18.6 & 65.4 & 51.3 & 40.8 & 15.8 \\
\hline USVL043 & $\mathrm{DH}$ & 5.9 & 6.5 & 10.4 & 11.9 & 25.6 & 23.8 & 6.8 & 12.1 \\
\hline USVL036 & $\mathrm{DH}$ & 24.6 & 26.1 & 35.3 & 36.0 & 51.9 & 61.3 & 14.0 & 18.0 \\
\hline Pinnacle & $\mathrm{F} 1$ & 96.8 & 107.5 & 86.8 & 98.4 & 71.5 & 42.0 & 23.2 & 33.4 \\
\hline $\mathrm{LSD}_{0.05}$ & & 9.8 & 18.7 & 12.1 & 9.1 & 119.2 & 138.1 & 54.7 & 112.5 \\
\hline
\end{tabular}

Table 3. Mean glucoiberin (GI) concentration ( $\mu \mathrm{mol} \cdot \mathrm{g}^{-1}$ seed) and total GI yield ( $\mu \mathrm{mol} / \mathrm{plant}$ ) for seed harvested from self-compatible inbreds grown in two greenhouse and two outdoor cage environments. Sources of inbreds include open-pollinated (OP) varieties or doubled haploid (DH) populations. The hybrid (F1) 'Pinnacle' was included as a check.

\begin{tabular}{|c|c|c|c|c|c|c|c|c|c|}
\hline \multirow{4}{*}{$\begin{array}{l}\text { Broccoli } \\
\text { inbred }\end{array}$} & \multirow[b]{4}{*}{ Source } & \multicolumn{4}{|c|}{ Concn $\left(\mu \mathrm{mol} \cdot \mathrm{g}^{-1}\right.$ seed $)$} & \multicolumn{4}{|c|}{ Yield ( $\mu$ mol/plant) } \\
\hline & & $\mathrm{GH}$ & $\mathrm{GH}$ & Cage & $\overline{\text { Cage }}$ & $\mathrm{GH}$ & $\mathrm{GH}$ & Cage & Cage \\
\hline & & 1999- & $2000-$ & $2000-$ & 2001- & 1999- & $2000-$ & 2000 & 2001- \\
\hline & & 2000 & 2001 & 2001 & 2002 & 2000 & 2001 & 2001 & 2002 \\
\hline$\overline{\text { USVL102 }}$ & $\mathrm{OP}$ & 10.2 & 0.0 & 0.0 & 0.0 & 8.4 & 0.0 & 0.0 & 0.0 \\
\hline USVL104 & $\mathrm{OP}$ & 0.5 & 0.0 & 0.0 & 0.0 & 3.7 & 0.0 & 0.0 & 0.0 \\
\hline USVL103 & $\mathrm{OP}$ & 11.6 & 12.2 & 10.3 & 12.5 & 6.9 & 4.5 & 28.2 & 18.5 \\
\hline USVL049 & $\mathrm{DH}$ & 0.0 & 0.0 & 0.0 & 0.0 & 0.0 & 0.0 & 0.0 & 0.0 \\
\hline USVL062 & $\mathrm{DH}$ & 5.1 & 15.3 & 3.3 & 4.2 & 18.9 & 26.3 & 13.1 & 12.8 \\
\hline USVL093 & $\mathrm{DH}$ & 4.7 & 5.9 & 6.3 & 7.1 & 17.9 & 21.6 & 8.9 & 20.3 \\
\hline USVL020 & DH & 1.9 & 4.1 & 1.8 & 2.1 & 4.2 & 8.4 & 3.7 & 4.8 \\
\hline USVL028 & $\mathrm{DH}$ & 29.3 & 39.4 & 38.5 & 31.6 & 77.7 & 61.7 & 59.0 & 24.4 \\
\hline USVL043 & $\mathrm{DH}$ & 2.3 & 2.8 & 4.2 & 3.8 & 9.8 & 10.5 & 2.7 & 3.9 \\
\hline USVL036 & $\mathrm{DH}$ & 7.9 & 8.8 & 12.5 & 11.1 & 16.6 & 20.2 & 4.9 & 5.7 \\
\hline Pinnacle & $\mathrm{F} 1$ & 0.0 & 0.0 & 0.0 & 0.0 & 0.0 & 0.0 & 0.0 & 0.0 \\
\hline $\mathrm{LSD}_{005}$ & & 7.7 & 4.7 & 3.1 & 5.4 & 21.4 & 19.8 & 18.1 & 10.5 \\
\hline
\end{tabular}

glucoraphanin concentrations and b) expression of this trait is consistent across different environments.

Total per-plant yield of glucoraphanin parallels results for glucoraphanin concentration, although separation of means was less pronounced for this characteristic (Table 2). Farnham and Harrison (2003) noted that plant-to-plant seed yield variation resulted in relatively high coefficients of variation for varieties in which seed weight was measured. Because total per-plant glucoraphanin yield is the product of seed weight and glucoraphanin concentration, the high seed weight variances also made separation of glucoraphanin yield means problematic. Although most lines did not yield significantly different amounts of glucoraphanin, USVL102, USVL104, and USVL049 usually had significantly greater yields than all the others (Table 2). Except for a few environments, these inbreds had $>10$-fold greater mean glucoraphanin yields than the lowest yielding inbreds. In general, seed from these three inbreds exhibited relatively high glucoraphanin concentration combined with a moderate to high seed yield.

USVL043 and USVL062 usually exhibited the lowest glucoraphanin yields (Table 2). 'Pinnacle' too, exhibited low glucoraphanin yield even though it always had high concentrations; this was a consequence of very low seed yields. Apparently, good seed yields with USVL043 and USVL062 did not compensate for their low glucoraphanin concentration, and they yielded relatively little glucoraphanin. Likewise, high concentrations for 'Pinnacle' failed to compensate for this cultivar's low seed yield. The high concentration of glucoraphanin in 'Pinnacle' may result from deposition of glucoraphanin into a very limited seed sink. Unlike seed from inbred lines evaluated in this study, seed harvested from 'Pinnacle' is $F_{2}$ seed, and thus, there is a high level of heterozygosity in its seed lots.

Rangkadilok et al. (2002) measured higher seed glucoraphanin concentrations (i.e., $>100$ $\left.\mu \mathrm{mol} \cdot \mathrm{g}^{-1}\right)$ in most of their entries than we report for self-compatible inbreds herein. However, it appears that most of the entries measured by Rangkadilok et al. (2002) are either $F_{1}$ hybrids or the more common type of broccoli inbred that is self-incompatible. The highest concentrations we observed for 'Pinnacle' and those observed by Rangkadilok et al. (2002) may occur due to hybrid vigor for glucoraphanin concentration or due to the [observed] elevation in concentration when seed yield is limited. This, in turn, could explain the high levels in self-incompatible inbreds that will only produce limited seed when bud pollinations are conducted.

Unlike the results observed for glucoraphain, there were no significant effects of environment on glucoiberin concentration or yield (Table 1). In addition, only glucoiberin concentration had a significant genotype $x$ environment interaction. Since it is generally a minor component of broccoli tissues, glucoiberin was not specifically evaluated in most previous studies. Self-compatible inbreds analyzed herein exhibited relatively consistent glucoiberin concentrations across the four environments (Table 3). Except in a few instances, mean concentration and rank of entries did not change significantly. For instance, glucoiberin was never detected in USVL049 or 'Pinnacle', and glucoiberin concentration was always highest (about 30 $\mu \mathrm{mol} \cdot \mathrm{g}^{-1}$ or higher) in USVL028. In three out of four environments, glucoiberin was also not detected in USVL102 or USVL104. The only significant shifts for glucoiberin were a moderate concentration in the 1998-99 greenhouse for USVL102 and a moderate level in USVL062 in the 2000 greenhouse. Although the average coefficient (0.82) from Spearman rank correlation of glucoiberin concentration between environments was lower than for glucoraphanin, it was still highly significant. As with glucoraphanin, these data for glucoiberin show that seed produced by different broccoli genotypes in a single environment exhibit significantly different glucoiberin concentrations that tend to be consistent when compared across different environments.

Trends for glucoiberin yields were similar to those for their concentrations (Table 3). As with glucoraphanin, mean separations for glucoiberin yields were less effective than those 
for concentrations. In general, inbreds that exhibited the highest glucoiberin concentrations, like USVL028 in all environments, and USVL103 in screen cage environments, also exhibited the highest glucoiberin yields.

Fahey et al. (1997) concluded that broccoli seed contains 10 to 100 times more glucoraphanin than broccoli florets. Other studies (Brown et al., 2003; Farnham et al., 2000; Kushad et al., 1999) have clearly shown that floret concentration of glucoraphanin can vary widely by genotype, but clarity about the source of this variation has been confounded by issues of environmental affects upon the vegetative tissue being analyzed. We now demonstrate that the same wide variation in concentration exists in broccoli seed. It is true that in some cases (e.g., with USVL104 and USVL049) seed concentration can be up to 100 times greater than concentrations of glucoraphanin observed in florets (when expressed on a dry weight basis). However, in other cases (e.g., USVL043 and USVL062), concentration of seed glucoraphanin probably does not exceed concentration of glucoraphanin in floret dry matter.

In many cases in which we observed high concentrations of glucoraphanin, glucoiberin was not detected (Tables 2 and 3). Likewise, when high glucoiberin was observed it was usually accompanied by intermediate glucoraphanin concentrations. Statistical analysis indicated a significant $(P<0.01)$, yet weak, negative correlation coefficient $(r$ $=-0.30$ ) between mean concentrations of the two glucosinolates. Because glucoraphanin and glucoiberin are closely related from a biosynthetic standpoint (i.e., glucoiberin is a propyl-methonine derivative rather than a butyl derivative), there may be metabolic competition for carbon skeletons in their biosynthesis. It may be possible to combine high glucoraphanin and glucoiberin seed concentrations in a highyielding inbred. However, the advantage of added glucoiberin is uncertain, since previous studies have shown that the phase 2 inducing potential of its cognate isothiocyanate (iberin) is only $10 \%$ that of sulforaphane (Prestera et al., 1993; Zhang et al., 1992). Several inbreds, USVL104 and USVL049, described in this study appear to combine both high glucoraphanin concentration and high per plant yield of this phytochemical. These lines may be of interest to seed producers interested in optimizing glucoraphanin yield from seed for the production of sulforaphane as a fine chemical.

\section{Literature Cited}

Brooks, J.D., V.G. Paton, and G. Vidanes. 2001. Potent induction of phase 2 enzymes in human prostate cells by sulforaphane. Cancer Epidemiol. Biomark. Prevent. 10:949-954.

Brown, A.F., G.G. Yousef, E.H. Jeffery, B.P. Klein, M.A. Wallig, M.M. Kushad, J.A. Juvik. 2002. Glucosinolate profiles in broccoli: Variation in levels and implication in breeding for cancer chemoprotection. J. Amer. Soc. Hort. Sci. 127:807-813
Carlson, D.G., M.E. Daxenbichler, C.H. vanEtten, W.F. Kwolek, and P.H. Williams. 1987. Glucosinolates in crucifer vegetables: Broccoli, Brussels sprouts, cauliflower, collards, kale, mustard greens, and kohlrabi. J. Amer. Soc. Hort. Sci. 112:173-178.

Fahey, J.W. , X. Haristoy, P.M. Dolan, T.W. Kensler, I. Scholtus, K.K. Stephenson, P. Talalay and A. Lozniewski. 2002. Sulforaphane inhibits extracellular, intracellular, and antibiotic-resistant strains of Helicobacter pylori and prevents benzo[a]pydrene-induced stomach tumors. Proc. Natl. Acad. Sci. USA 99(11):7610-7615.

Fahey, J.W. and P. Talalay. 1999. Antioxidant functions of sulforaphane: a potent inducer of Phase II detoxication enzymes. Food Chem. Toxicol. 37:973-979.

Fahey, J.W., A.T. Zalcmann, and P. Talalay. 2001. The chemical diversity and distribution of glucosinolates and isothiocyanates among plants. Phytochemistry 56:5-51 Corrigendum (2002) Phytochemistry 59(2):237.

Fahey, J.W., Y. Zhang, and P. Talalay. 1997. Broccoli sprouts: An exceptionally rich source of inducers of enzymes that protect against chemical carcinogens. Proc. Natl. Acad. Sci. USA 94:10367-10372.

Farnham, M.W. 1998. Doubled haploid broccoli production using anther culture: Effect of anther source and seed set characteristics of derived lines. J. Amer. Soc. Hort. Sci. 123:73-77.

Farnham, M.W. and H.F. Harrison. 2003. Using self-compatible inbreds of broccoli as seed producers. HortScience 38:85-87.

Farnham, M.W., K.K. Stephenson, and J.W. Fahey. 2000. Capacity of broccoli to induce a mammalian chemoprotective enzyme varies among inbred lines. J. Amer. Soc. Hort. Sci. 125:482-488.

Farnham, M.W., K.K. Stephenson, and J.W. Fahey. 2004. Genetic and environmental effects on glucosinolate content and chemoprotective potency of broccoli. Plant Breeding 123:60-65.

Faulkner, K., R. Mithen, and G. Williamson. 1998. Selective increase of the potential anticarcinogen 4-methylsulphinylbutyl glucosinolate in broccoli. Carcinogenesis 19:605-609.

Giamoustaris, A. and R. Mithen. 1996. Genetics of aliphatic glucosinolates. IV. Side-chain modification in Brassica oleracea. Theor. Appl. Genet. 93:1006-1010.

Gray, A.R. 1993. Broccoli, Brassica oleracea L. (Italica group), p. 61-86. In: G. Kalloo and B.O. Bergh (eds.). Genetic improvement of vegetable crops. Pergamon Press, Oxford.

Haristory, X., K. Angioi-Duprez, A. Duprez, A. Lozniewski. 2003. Efficacy of sulforaphane in eradicating Helicobacter pylori in human gastric xenografts implanted in nude mice. Antimicrob. Agents Chemotherapy 47(12):3982-3984.

Jackson, S.J.T. and K.W. Singletary. 2004. Sulforaphane: A naturally occurring mammary carcinoma mitotic inhibitor, which disrupts tubulin polymerization. Carcinogenesis 25(2):219-227.

Kushad, M.M., A.F. Brown, A.C. Kurlich, J.A. Juvik, B.P. Klein, M.A. Wallig, and E.H. Jeffery. 1999. Variation of glucosinolates in vegetable crops of Brassica oleracea. J. Agr. Food Chem. 47:1541-1548.

Li, G., A. Riaz, S. Goyal, S. Abel, and C.F. Quiros. 2002. Inheritance of three major genes involved in the synthesis of aliphatic glucosinolates in Brassica oleracea. J. Amer. Soc. Hort. Sci. 126:427-431.
Moore, J.F. and T.H. Antsey. 1954. A study of the degree of natural selfing in green sprouting broccoli (Brassica oleracea L. var. Italica Plenck.), a normally cross-pollinated crop. Proc. Amer. Soc. Hort. Sci. 63:440-442.

Pereira, F.M.V., E. Rosa, J.W. Fahey, K.K. Stephenson, R. Carvalho, and A. Aires. 2002. Influence of temperature and ontogeny on the levels of glucosinolates in Broccoli (Brassica oleracea var. italica) sprouts and their effect on the induction of mammalian phase 2 enzymes. J. Agr. Food Chem. 50:6239-6244.

Prestera, T., J. W. Fahey, W. D. Holtzclaw, C. Abeygunawardana, J. L. Kachinski, and P. Talalay. 1996. Comprehensive chromatographic and spectroscopic methods for the separation and identification of intact glucosinolates. Anal. Biochem. 239:168-179.

Prestera T., Y. Zhang, S. R. Spencer, C. Wilczak, and P. Talalay. 1993. The electrophile counterattack response: Protection against neoplasia and toxicity. Adv. Enzyme Regulat. 33:281-296.

Rangkadilok, N, M.E. Nicolas, R. N. Bennet, R.R. Premier, D.R. Eagling, P.W.J. Taylor. 2002. Determination of sinigrin and glucoraphanin in Brassica species using a simple extraction method combined with ion-pair HPLC analysis. Scientia Hort. 96:27-41.

Rosa E.A. S., R.K. Heaney, G.R. Fenwick, and C.A.M. Portas. 1997. Glucosinolates in crop plants. Hort. Rev. 19:99-215.

Rosa, E.A.S. and A.S. Rodrigues. 2001. Total and individual glucosinolate content in 11 broccoli cultivars grown in early and late seasons. HortScience 36:56-59.

Shapiro T.A., J.W. Fahey, K.L. Wade, K.K. Stephenson, and P. Talalay. 1998. Human metabolism and excretion of cancer chemoprotective glucosinolates and isothiocyanates of cruciferous vegetables. Cancer Epidemiol. Biomark. Prev. 7:1091-1100.

Shelp, B.J., L. Liu, and D. McLellan. 1993. Glucosinolate composition of broccoli (Brassica oleracea var. italica) grown under various boron treatments at three Ontario sites. Can. J. Plant Sci. 73:885-888.

Singh, A.V., D. Xiao, K.L. Lew, R. Dhir, and S.V. Singh. 2004. Sulforaphane induces caspase-mediated apoptosis in cultured PC-3 human prostate cancer cells and retards growth of PC-3 xenografts in vivo. Carcinogenesis 25(1):83-90.

Troyer, J.K., K.K. Stephenson, and J.W. Fahey. 2001. Analysis of glucosinolates from broccoli and other cruciferous vegetables by hydrophilic interaction liquid chromatography. J. Chromotog. A 919:299-304.

Velasco, L. and H.C. Becker. 2000. Variability for seed glucosinolates in a germplasm collection of the genus Brassica. Genet. Resour. Crop Evol. 47:231-238.

Wu, L. and B.H.J. Juurlink. 2001. The impaired glutathione system and its up-regulation by sulforaphane in vascular smooth muscle cells from spontaneous hypertensive rates. J. Hypertension 19:1819-1825.

Zhang, Y., T.W. Kensler, C.G. Cho, G.H. Posner, and P. Talalay. 1994. Anticarcinogenic activities of sulforaphane and structurally related synthetic norbornyl isothiocyanates. Proc. Natl. Acad. Sci. USA 91:3147-3150.

Zhang, Y., P. Talalay, C.G. Cho, and G.H. Posner. 1992. A major inducer of anticarcinogenic protective enzymes from broccoli: Isolation and elucidation of structure. Proc. Natl. Acad. Sci. USA 89:2399-2403. 